Contributorship and Partial Inclusion: A Communicative Perspective

\author{
Nicolas Bencherki \\ State University of New York at Albany \\ nbencherki@albany.edu \\ TÉLUQ Montréal \\ nicolas.bencherki@teluq.ca \\ James P. Snack \\ State University of New York at Albany \\ jsnack@albany.edu
}

A more recent version is published as Bencherki, N. \& Snack, J. P. (2016). Contributorship and

Partial Inclusion: A Communicative Perspective. Management Communication Quarterly, 30(3), 279-304. doi: $10.1177 / 0893318915624163$. 


\begin{abstract}
Organizational communication tends to assume that the practices of organizational "members" are relevant to the study of organizational phenomena, without reflecting on how those members were identified in the first place. This issue is particularly relevant to perspectives that view communication as constitutive of organizations, since they may take the very object they seek to explain - the organization - as the starting point when identifying pertinent informants. We provide a communicational perspective of organizational membership by starting from “communicative events" (Schoeneborn \& Scherer, 2012), instead of individuals. Ethnomethodology's notions of accounts and sanctions are useful in recognizing the interactionally-performed nature of membership. We extend ethnomethodology's intuition by viewing membership - which we reframe as contributorship - as being achieved through the contribution of actions to the organization.
\end{abstract}

Keywords: membership; communicational constitution of organizations; organizational communication; ethnography; organizational action. 
Contributorship and Partial Inclusion: A Communicative Perspective

Interpretive and constitutive approaches to organizational communication (Taylor, Flanagin, Cheney, \& Seibold, 2001) share a concern for what individuals say when speaking about organizational realities, either to uncover their meaning or to constitute them. However, an important assumption these approaches make is that the individuals to be interviewed or observed are the organization's members: it is taken for granted a) that such members are simple to identify; and b) that what they say or do makes a difference for that specific organization, whose boundaries are clearly delimited. While organizational communication researchers are increasingly willing to acknowledge managerial, gender or racial biases (Lee Ashcraft \& Allen, 2003), thus extending organizational membership to hitherto overlooked individuals, there remains a strong "membership bias." We, organizational communication researchers, simply assume that the discourse of a certain set of people - one category or another of "formal" members - is relevant to the organizational phenomena we wish to explain.

This is particularly a problem in the case of constitutive approaches, including the literature that has come to be known as the "Communicative Constitution of Organizations" or CCO (McPhee \& Zaug, 2000; Putnam \& Nicotera, 2009). Indeed, while studies in that approach claim to question the taken-for-grantedness of organizations and to study how they come to be constituted in the first place, they run a serious risk of taking an already-constituted organization as their starting point by presuming a coherent and non-problematic set of "members" whose relationship with the organization is allegedly obvious.

Such assumptions were perhaps acceptable when organizations were perceived as large, stable and enduring (if there ever was such a time) and when organizational communication concerned itself only with businesses and public administrations. However, it is now increasingly 
evident that organizations take a variety of forms and that change is the norm rather than the exception (Tsoukas \& Chia, 2002). Furthermore, organizational communication has now extended its interests beyond the wall of conventional organizations to embrace a variety of alternative types of collectives. These evolutions have led authors to propose that the definition of organizational membership is more difficult than it may appear. This is true in businesses and formal organizations, where contract workers and consultants (Barley \& Kunda, 2004; Gossett, 2006; Wright, 2009), teleworkers (Hylmö, 2006) and other new forms of work (Ainsworth \& Hardy, 2008; Raman, 2001), as well as evolving conceptions of career (Heaphy, 2013), blur the boundaries of membership. That said, it is perhaps more readily visible in the case of community organizations, where membership is characterized by ambiguity, complexity and change (Huxham \& Vangen, 2000): challenges include sometimes limited knowledge of others’ membership status and organizational belonging, given complex partnerships with overlapping members. Community workers are torn between an ideal of volunteering and a trend towards professionalization (Ganesh \& McAllum, 2012), along with tensions with respect to the formalization of activity and the socialization of newcomers (McNamee \& Peterson, 2014). While volunteering is not conventional paid work, it nonetheless creates organizational affiliations (McAllum, 2014). In addition, community organizations are impacted by government policies, collaborations with private and public organizations, and other exogenous factors. There is no reason to suppose, however, that the ambiguity and, indeed, confusion with respect to membership in community organizations are peculiar to the non-profit sector: they also exist, albeit perhaps to varying degrees, in other forms of organizations. For instance, Lawrence (2004) recognizes that professions may also experience varying degrees of formality in the rituals by which members and non-members are distinguished. 
In spite of acknowledgements of the difficulty to pinpoint a single form of organizational membership, organizational communication's theory lags behind its empirical observations in that respect. In particular, while the CCO tradition is well-established and has proven its ability to account for the (re)production of organizations and related phenomena (Ashcraft, Kuhn, \& Cooren, 2009; Putnam \& Nicotera, 2009), it has yet to reflect on its own conception of membership. Just like other traditions, CCO's assumptions rest on an underdeveloped conception of membership: it supposes that members discuss, talk, write or otherwise communicate to constitute, reproduce and grant endurance to "their" organization. Of the various streams of CCO - Robert McPhee's Four Flows model, the Montreal School and the Luhmannian approach (Schoeneborn et al., 2014) - only the Four Flows model has a clear concern for the way membership is communicatively established, membership negotiation being one of the "flows" (McPhee \& Iverson, 2009; McPhee \& Zaug, 2000). However, the Four Flow's reliance on Giddens' structuration theory (see e.g., Giddens, 1984) situates its discussion of membership negotiation at a general level rather than at that of the precise interactional mechanisms that the word "negotiation" may imply, perhaps because "Giddens was notoriously brief in his discussion of communication" (McPhee \& Iverson, 2009, p. 52). While structuration theory has elicited some interest towards the issue of membership (Scott, Corman, \& Cheney, 1998), more recently, Schoeneborn and Scherer (2012) frontally addressed the taken-for-grantedness of membership in some CCO literature and call for renewed attention to its communicational details. They comment on Stohl and Stohl's (2011) study of communication between members of clandestine organizations, and stress the importance of considering communicative events as they happen, without limiting the analysis to pre-determined boundaries, for organizations "cannot decide about who is a member and who is not" (p. 966). While they discuss the convoluted membership 
of clandestine organizations, different sorts of organizations - including community organizations - comprise people whose relationship cannot be accounted for entirely by formal membership.

We respond to Schoeneborn and Scherer's invitation, and provide a more interactional lens to McPhee's discussion of membership negotiation. This discussion will show a) that CCO already provides the theoretical and analytical apparatus to describe (a variant of) membership; and b) that, in doing so, CCO may provide a genuinely communicative approach to membership, that starts with the observation of concrete practices rather than with any a priori categorization of people into members and non-members. Our theoretical vantage point will be that of the Montreal School approach (hereafter TMS; see Brummans, 2006), which draws attention to interactions (Cooren, 2007) and their ability to "scale up" to constitute organizations (Cooren \& Fairhurst, 2008). We consider that "communicative events" are about actions - or more precisely, as François Cooren explained during a roundtable, "we could say that communication is, first and foremost, considered an action" (Schoeneborn et al., 2014, p. 289). Indeed, in the TMS perspective, communication is viewed as a situated practice that consists of doing something, including through speech acts (Austin, 1962; Co-author \& Author; Cooren, 2004a; Searle, 1969); these actions are the building blocks of organizations. Focusing on speech acts allows for observing the way actions are communicatively attributed to the organization (Bencherki \& Cooren, 2011). These attributions, we argue, contribute to populating the organization with what we propose to call "contributors," in order to distinguish them from formal members.

To support this claim, we need to question the conception of the contributor/member as a complete individual and show that people, whether they are formal members or not, belong to 
the organization only on the basis of some of their actions - in other words, we will suggest that people are "dividuals" (Deleuze, 1992). This argument rests on TMS' relational and "hybrid" conception of (social) reality, which acknowledges that many things, besides human individuals, can act (Cooren, 2006; Cooren, Fox, Robichaud, \& Talih, 2005). Analysis, therefore, should not start from complete people, but rather at the pre-individual level of actions. We then offer a take on the way those actions that make up people are communicatively attributed to the organization, and how, in doing so, both the organization and the contributor are constituted. Empirical illustrations will then provide some flesh to those claims.

\section{The complexity of membership}

McPhee and Zaug's (2000) description of membership negotiation recognizes that "in constituting members, the communication process importantly constitutes the organization, since one must be a member of something." However, as McPhee and Iverson (2009, p. 63) point out, formal membership is not enough to account for people's participation in organizations. In spite of these two important acknowledgements, the Four Flows model leaves unanswered the precise form the communication process of membership negotiation could take, and how formal membership could be supplemented with others forms of contributions to the organization.

Other attempts at elucidating people's membership of "their" organization pose two issues: they in fact take for granted that the people under study are indeed members, and they suppose that the organization exists independently of those people. The question, then, is the match between individuals and the organization. In particular, membership has been addressed in discussions of identity and identification (Ashforth \& Mael, 1989; Pratt, 2000). Literature on organizational identification draws attention to competing identities, but only rarely problematizes membership as being equally fractured. Even authors who acknowledge 
overlapping identities, including Scott, Corman and Cheney (1998), do not question organizational boundaries or the idea that relevant processes are limited to "identification with various targets within the organizational context” (p. 300). Said otherwise, organizational boundaries and members are presumed, and identification is a matter of deciding the exact components of the organization to which people are attached, the intensity of that attachment, and what actions should be carried out as part of that identification. Sources of identity or identification may lie outside a formal organization (for instance, in profession, occupation, or family), but in all cases what is at stake is the ability to find coherence between one's identity and the organization - action naturally follows (Meisenbach \& Kramer, 2014). As Cheney (1983) writes, "members 'act out' their identification with the organization."

However, exceptions in organizational identification literature point to possible alternative understandings of the member-organization relationship. For instance, Henderson, Cheney and Weaver (2015) take the case of two different farmers' organizations to examine how organizational identification concerns not only members as such, but also a variety of stakeholders. Another case, closer to our own understanding, is that of Chaput, Brummans and Cooren (2011, p. 253) who, through the notion of consubstantiation, illustrate how people's identification with the organization "occurs during everyday interactions" and also constitutes substantiates - the latter. This idea leads to an understanding of the communicative constitution of organizations where members are not presumed but where, instead, belonging is viewed as a process that is co-extensive with organizational becoming. Yet another example is Koschmann's (2013) study of the way an inter-organizational partnership fostered collective action through a communicatively-constituted authoritative text. This text crystallized a collective identity and a sense of common action. We would like to extend these insights into a systematic exploration of 
the way people are recognized as contributors to organizations, without supposing who they are, or to what organization they are contributing.

Munro (1999) provided a communicational understanding of organizational membership by borrowing from Garfinkel's (1967) ethnomethodology, as does, albeit differently, TMS (Cooren, 2007). For Munro, it is in sanctioning each other's skilful accounting for one's actions that participants recognize each other as competent members of the organization. However, what ethnomethodology covers with the term "membership" is far from what is usually meant by that term in organizational contexts. For instance, Butler and Fitzgerald (2010) show that membership is related to identity and is interactionally performed, but their ethnomethodological use of the term refers to the interactional roles of participants and the activities that are bound to them. Despite this unorthodox borrowing of ethnomethodology's sense of membership, the notion has heuristic import in two ways. First, it points to the fact that research "is not interested in 'individuals' as such, but in the competences involved" (Have, 2002, p. 14), which is close to the focus on action we suggest. Second, we agree with ethnomethodology's recognition that membership, rather than a given, "is only ever provisional" (Munro, 1999). In addition, it admits that membership is an issue to analysts, but also to participants themselves, as "within daily practice $[. .$.$] questions of membership are seldom fully settled; they usually remain as$ questions" (p. 445). That participants themselves can be - but are not constantly - engaged with questions of membership suggests that the decision of who is a member is not only a theoretical or analytical matter, but also an observable and empirical problem, that may be more or less durably stabilized. 


\section{Organizational Dividuals}

French philosopher Gilles Deleuze (1992) coined the term "dividuals" to stress that people can no longer be considered as in-dividuals, i.e., complete, self-sufficient coherent entities. Technologies of control - think of the time clock - bind various facets of a single person to so many elements of society, thus fracturing and compartmentalizing people. Much earlier, sociologist Gabriel Tarde (1893) similarly stated that people are "societies" and that "the attributes that persons owe to their incorporation in their regiment do not constitute all of their nature; they have other inclinations, other instincts, that come from different inclusions" (p. 39, we translate). Both views suggest that people and organizations alike may appear to be unitary "selves," but that this is the result of intricate processes that need to be described.

Said otherwise, people are not whole, coherent entities that fit in a single organization, in the same way as the Matryoshka dolls nest within each other. Rather, they each constitute societies that hold together the many "pre-individual" elements that constitute them. Those preindividual elements are engaged in various ways with different collectives - including human beings - and relate to each other through a variety of means, language and communication being among them. This idea has been more completely developed by Gilbert Simondon (2005, first published in 1958), who Deleuze often cited, and who wrote of the "individuation" process, meaning that becoming an individual is an achievement, rather than a starting point. Being able to hold together the various "pre-individual" components that make us up and integrating them into an individual self is a continuous - and communicative - feat.

Closer to organizational communication literature, Weick (1979) recognizes that "organizations are grounded in interlocked behaviors rather than interlocked people," before remarking that only some of people's actions are organizational in nature: there are no total 
inclusions, only partial inclusions. People do not either stay or leave, but can do both because "any person is typically a member of several groups" (p. 96). It is the possession of some of a person's actions by the organization that, in turn, makes the person a "member" (whether this is formally recognized or not) of the organization. To a certain extent and under some aspects, “only selected behaviors of individuals are necessary for organizational functioning” (p. 96). We contend that the way this selection of behaviors - we prefer calling them actions - and their attribution to the organization are achieved is what is genuinely communicational about membership. This does not mean that people's partial and communicative membership is any less sincere or real than a hypothetical "full" commitment. As another French philosopher, Jacques Derrida, notes, it is possible to be "fully" a member of a community while not being a member "in entirety," that is, through and through ("de part en part," Derrida, 1991, p. 80, we translate).

The notion of partial inclusion - i.e., the attribution of some of one's actions to the organization - is not equivalent to discussions of identity salience, self-categorizations or other identity or role-based views (Hogg \& Reid, 2006; Kuhn \& Nelson, 2002). The concept of identity, even if it admits multiplicity and fragmentation, still considers the single, whole individual as the pertinent unit of analysis and views action as the result of that person's sensemaking of the situation and of the relevant role he or she has to play. In the words of Gilbert Simondon, such views grant "an ontological privilege to the constituted individual" (2005, p. 23). Membership, therefore, is taken for granted, and what constitutes a mystery is the ability of people to recognize what actions they need to perform as part of that membership.

Yet, sensemaking, as Weick (1995) explains, is retrospective - actions come first, and their meaning is determined after the fact (even though, in the flow of events, the priority 
between action and understanding amounts to the chicken and egg problem). Munro's (1999) suggestion that it is the sanction of people's competent accounts of their actions (rather than, say, decision over what actions to perform) that constitutes membership allows recognizing that the relation between action and understanding is not an abstract feat but rather a practical accomplishment: it is not the deed of Rodin's Thinker but rather that of a network of Tinkerers (Latour, 2008).

In sum, our proposal is that membership is not only about people being (formally) part of an organization; it is also about some of people's actions being attributed to the organization as the result of interactional performances. While we can think of people who retain formal membership while not contributing to the organization, this is exactly no more than an administrative tie that, we argue, would not in most situations be picked up by actors in day-today interactions, even though it does have effects of its own. This proposal rests on the assumption that people are not unitary, indivisible individuals, but rather beings whose communicative activities consist both in the constitution of "their" organization and in the integration of their multiple actions (including communicative actions) into more or less stable constructs of individuality. Members, thus, constitute themselves as they constitute the organizations to which they participate. For the sake of clarity, we will reserve from now on the concept of membership for the formal view, and instead call our more processual and communicative version "contributorship," even though this word has a history of its own. "Members" will become, for their part, "contributors," to insist that it is inasmuch as they share actions with an organization that they may, so to speak, belong to it. 


\section{The communicative performance of contributorship}

If we depart from a conception of membership as the inclusion of complete individuals into the organization and espouse instead a view of singular actions being attributed to it, then we need, as Schoeneborn \& Scherer (2012) note, to focus on the communicative events as they unfold and attempt to witness the ways in which they are related and brought together into contributors and organizations, and how they tie the two together.

Our starting point rests on Munro’s (1999) insight that, in an ethnomethodological perspective, positive sanction of accounts of action is constitutive of membership. As Garfinkel (1967, p. vii) explains, people's actions are “visibly-rational-and-reportable-for-all-practicalpurposes, i.e., 'accountable."' When an action fails to be recognized as the token of a rule, then, according to Garfinkel, the person must provide an account to explain how the action follows a shared rule (this is the "documentary method," 1967, p. 40). The acceptance of the account by interlocutors means they acknowledge the person as a skilled member of the organization, given that they display their knowledge of its rules. We would like to extend the idea further. While ethnomethodology takes action as its starting point and recognizes the retrospective nature of sensemaking, it overlooks two aspects of accounting practices.

The first is that providing an account amounts to establishing a relationship between the action under scrutiny and a particular reason that makes it sensible and recognizable. When interlocutors sanction a performance, the invoked reasons are collectively made to share the authorship of the action being assessed (Cooren, 2004a, 2010). Van Vuuren and Cooren (2010), for example, propose that attitudes are not only excuses for behavior; they also play an active part in action and, as such, may be seen to have agency. Invoking reasons, justifications or causes also entails communicatively attributing action to those things that are summoned, and 
provisioning existence and agency to those figures (Bencherki \& Cooren, 2011). In other words, when our businesses other collectives are mobilized in talk to "lend weight" to our actions (Cooren, 2010, p. 9), then participants are also contributing to the communicative constitution and action of those organizations.

The second overlooked aspect of accounting is that it consists not only in a justification, but also in the enrolment of those figures to allow the action of the speaker to gain weight or, indeed, to happen at all. Following actor-network theory, we could say that a single actor cannot, in fact, act - the actor needs a network of allies to act on his/her/its behalf (see e.g., Cooren, 2010). In different traditions, the need for reasons, principles, justifications, rules, etc., in order to act can also be traced in Boltanski and Thévenot's (2006) social pragmatics or in Burke's (1950) notion of motives. Another way of understanding this idea is by saying that the actor, in invoking others as a justification of his or her action, is also made able to act, or authorized by them. In other words, they are constituted as an author of those actions (Benoit-Barné \& Cooren, 2009; Taylor \& Van Every, 2011, 2014).

It is important to note that this constitution of the actor is only achieved with respect to those actions that have been attributed to the organization by virtue of accounting practices. S/he is an actor or an agent of the organization that s/he helped constitute only inasmuch as s/he contributes (some) actions to that constitution. The three processes - accounting for actions, constituting the organization by sharing actions with it and constituting oneself as an organizational actor or contributor by being authorized - are three outcomes of a single practice.

Another noteworthy dimension of accounting is that it is agnostic to the particularities of the action being accounted for (Callon, 1986). For instance, it is indifferent to the action's place 
and time, as people regularly report on events that happened elsewhere and at some other times. This is crucial for the organization's ability to endure through time and space, as conversations weave together the here and the there, the then and the now (Cooren, 2004b; Cooren et al., 2005; Vásquez, 2013). This agnosticism also means that the action being accounted for does not need to be the actor's own; whether it is his or her action, rather than being an intrinsic characteristic of the action being deliberated, will be the result of the successful accounting performance. More importantly for us, action does not have to be a priori "organizational" - for, as we just mentioned, it is accounting practices that makes some actions organizational or not.

Membership or "contributorship," hence, is not a precondition to organizational action. It is rather a result of the successful attribution of actions to the organization. In negotiating roles, positions, footings or identities successfully, participants are not only describing them, they are also performing the contribution of actions to the organization. In doing so, persons become partial contributors to the many organizations in whose constitution and action they participate. For each organization - and we do recognize that they are regularly overlapping - it is from the perspective of those actions they share with the organization that they are contributors.

This view recognizes that people may be part of multiple organizations at once, which matters to community organizations whose partnerships weave a mesh of overlapping contributions (Ahrne \& Brunsson, 2005; Osborne \& Flynn, 1997). If we consider that people are members of "their" organization, which in turn is a member of the federation, then we miss a good proportion of what is going on and of the way the federation may act. A communicative view considers the negotiation of the authorship of action and allows showing that persons may be "fully" contributors to "their" organization while equally full contributing to the federations. 
A look at a two illustrative cases will highlight the usefulness of the perspective we sketch out. The first shows that formal membership does not do justice to the way people collectively negotiate the relationship between their actions and organizational agency. The second addresses more obviously the issue of membership to show that formal membership fails to account for the ways people relate to fellow organizational participants.

\section{Studying partial contributions}

Our theoretical proposal is the result of a multi-year ethnographic fieldwork that the first author conducted at a community organization working with the residents of an underprivileged district of a large Canadian city. Early in the process, it became obvious that the organization's employees, volunteers and board members worked regularly with people from other organizations and took part in activities that extended beyond the formal boundaries of "their" respective community groups.

Over the years, the first author audio- or video-recorded several meetings, whether within the organization's premises or elsewhere. They were informal meetings, team meetings, board meetings, or meetings at various partnership committees. The first author's involvement consisted in active participation, not only because it was necessary to gain access to the organization and because it provided with a unique insider's point of view, but also because the first author rapidly became a "convert" (Brannick \& Coghlan, 2007; Davis, 1973). The organization was a formal member of various partnerships and federations. We present here excerpts from two meetings. One is from the general meeting of a large federation that brings together organizations interested in social housing. The second is from a meeting of a local coalition of organizations, during which the conversion into a different legal status is being debated. 
It is obvious that the interpretations that we provide here are but illustrative. Many things are going on in these excerpts besides what catches our attention. The issue of the interpretation, validity and generalizability of ethnographic data is beyond the point of this paper (Goodall, 2000; Richardson, 2000; Van Maanen, 1979). We hope that at least, to quote American philosopher William James, readers will find a few "idea[s] upon which we can ride" (James, 1977, p. 382).

\section{The housing federation}

The following excerpt takes place during the general meeting of a federation of housingrelated organizations, bringing together over a hundred delegates. Frank, ${ }^{i}$ the federation's general director, chairs the meeting. Charles is the assistant director and serves as the meeting's secretary. Both are seated at a table at the front of the room. The two interventions take place early in the meeting, as they are presenting the federation's latest activities.

Frank: It's a preoccupation we've got here at the federation, to assist other groups that

2 are active elsewhere around the world. It's a concern that has come back on several occasions

3 and that got more tangible, among others, last summer when Jean visited us, and his presence at

4 the federation's congress and he took part in the two panel-debates that took place in Montréal

5 and in Québec City, and the different visits he made to different districts, in Québec City and in

6 Montréal. Also, it was already in my (represses laugh)... my trip was already planned in my, it

7 was paid through my (represses laugh) vacations, but I took advantage of my presence in France

8 to return the favor to Jean by taking part in a debate at the "Ministry of the housing crisis." It's a

9 building they squatted and that now houses families. And I took part also in a one-day retreat of

10 their housing federation in the suburbs of Paris. There was an article in the newsletter on housing

11 rights. 
13
(Applause, hubbub)

Charles: We need to mention too that Jerome from the Belleville Tenants' Association

various demonstrations for housing rights, he sent an email to us, here at the federation, asking

"can I say a word, in the name of federation, to say that we support their struggles, and all that?"

So we told him, "yes, go ahead." So he addressed the homeless families in France and people

were very happy to see someone there say in the name of the federation that we were supporting them.

(Applauses, hubbub)

In the first portion, Frank describes how he took advantage of his holidays in Paris to participate in a local housing association's activities. Different things could be said about this excerpt, for instance about Frank's apparent inability to achieve work-life balance. However, what is interesting is that, as he explains, those actions were not part of a mandate he was carrying out on behalf of his organization: he just happened to be there. Said otherwise, a conventional "delegational" view of organizational action fails to account for the way Frank's activities in Paris become those of the housing federation. It is the reporting of those actions that make them "organizational" and that retrospectively constitute him as having acted as a member when he was participating in those events. His performance, even though it may seem far from ethnomethodology's usual understanding of accounting, in fact displays the features referred to by Garfinkel (1967) and Munro (1999).

While there is no initial request made to Frank to explain his actions, the format of the meeting, where Frank reports on the organization's activities to the audience (who, ultimately, is his employer), clearly pressures him to craft his accounts in ways that make them recognizably relevant to the situation at hand. The introduction to his anecdote serves this purpose: he presents his anecdote as the realization of long-time organizational concerns for international 
collaborations and as a direct consequence of a previous visit to Montréal by his French counterpart. In other words, he crafts his account to present the federation - and its desire to extend its international activities - as a cause and therefore author of his actions in France.

He thus shares the authorship of those actions with the federation, which in turn authorizes him to perform them in its name (Taylor \& Van Every, 2014). Note that he is not claiming that his entire holidays were organizational, or even that everything he did with Jean was made in the name of the federation (we may suppose that they had coffee together andexchanged news about their families, and what not). Frank displays his "dividuality," in the sense that even if he is a full member of the federation, he is not a member of this organization "in entirety" (Derrida, 1991). He selects some of his actions and shares them, to some extent, with the organization.

That being said, Frank's skilful account does not suffice, in itself, to make his French escapade partially organizational. He also needs a positive sanction of his contribution (Munro, 1999). This happens when the crowd applauds when he finishes his account, followed by an indistinct chorus of positive comments (this is of course but one reading of the applause; alternative interpretations could be made). Another positive sanction consists in Charles' following turn of talk, during which he provides another similar story and which may be viewed as a confirmation of the relevance of Frank's intervention.

Charles, for his part, tells how Jerome, an employee of a member organization who also happened to be in Paris on a different occasion sent an email to ask whether he could speak on behalf of the federation. This is of interest in two ways. First, it illustrates the fact that being an employee of a member organization does not automatically constitute the person's actions as 
being "organizational." Jerome needed to ask for permission to present his speech as being also that of the federation. In doing so, he contributed his speech to the federation and presented himself as a (partial) member of the federation. Of course, this could be read as a "mere" obedience to organizational hierarchy, but it should be noted a) that Jerome is not directly a member of the federation, but rather an employee of a member organization, which means that he asked for permission to speak on behalf of an organization different from that of which he is a formal member; and b) that Jerome's example, even assuming that it did somehow follow institutional structures, still illustrates that the connection between a specific action and its "scaling up" to an organizational level needs to be negotiated, authorized, and attributed in communicative performance.

This excerpt also shows that a person can be recognized as a member of the federation and contribute to it "directly," even though formally only organizations are members of the federation, in addition to its few employees. Jerome's speech was contributing to the federation's action - the fact that he "really" was a member of an organization that in turn is a member of the federation is, in this case, irrelevant, and we could even imagine someone who is not an employee of a member organization (say, a self-employed housing rights lawyer) sending that email. Jerome, like Frank, displays dividuality in his ability to select some of his actions and share them with the federation. This second case also makes explicit that each organization may also be thought in terms of dividuality. The Belleville tenants' association, Jerome's employer, can also be said to have contributed an action to the federation, exactly because its own members can make a contribution at their own level.

It is through a communicative performance (at the moment when the action is brought to the general meeting) that a) Jerome's speech is representing and contributing its actions to the 
federation, $b$ ) the federation, as embodied by the delegates, authorizes and lends its weight to that speech and c) Jerome becomes, for the purpose of that speech, a contributor / representative / spokesperson of the federation. The more obvious communicative practices by which this is achieved are that Jerome asks for - and receives - authorization to speak on behalf of the federation and that, presumably, he tells his audience that he is authorized; he invokes the federation as sharing his action. However, as was the case with Frank, here Charles tells the story and is positively sanctioned by the applause and positive comments from the meeting's audience. This is important as it establishes that it is the federation - and not only the person who answered Jerome's email - who retrospectively authorized Jerome's speech, making it its speech (authorizing is a form of authoring). Charles' account performs the attribution of the act of authorizing to the federation, so that in turn the speech can be attributed to it.

\section{The community council}

The second case addresses more explicitly the issue of contributorship / membership, and consists in a conversation that took place during a meeting of an organization that serves as a coordination platform for community organizations working in an underprivileged district of Montréal. In preparation for this paper, we submitted this excerpt to a collective analysis with six colleagues from Montréal to confirm our interpretations. We will call the organization the Community Council. About twenty people attended the meeting, even though only a few of them spoke in the excerpt. We report here excerpts from the full transcript, which is provided as an appendix ${ }^{\text {ii }}$.

During the meeting, membership was the first item on the agenda and the part we quote dealt with membership categories. The Community Council, like other similar groups, allows affiliate organizations to choose between categories that reflect different levels of involvement in 
exchange for varying voting and participation privileges. The Community Council had to revise its membership categories as it applied to be recognized as a Community Development Corporation (CDC), a status that allows for greater representation at government forums. During the meeting, participants referred to a text that was provided to them and that laid out the typical bylaws of a CDC, which they could adapt to their specific context.

While they had always welcomed a variety of people from different organizations at their meetings, now participants were faced with the practical problem of defining what "being a member" means. The document prompts them to specify membership categories they had never considered and that, they fear, may exclude long-time collaborators.

This excerpt shows how people do not limit themselves to formal definitions of membership, even though they appear, at first, to be bounded by the categories mentioned in the document. As the full transcript shows, they dynamically set for themselves criteria of membership. They begin with the membership fees - who should pay how much - but when it turns out not to be a workable solution, they consider voting rights, before turning to organization types - whether candidate members are community organizations, government agencies, etc. Finally, they come up with a pragmatic solution, which distinguishes between formal membership and actual contribution to the organization. Throughout, we can discern a concern to keep around the table those people who have been making valued contributions. The various definitions of membership are so many attempts to negotiate between the text's suggested categories and the reality of who actually makes a difference to them. This case shows that people value the contribution of non-members, and do not, in everyday business, question their formal status. The document puts participants in the artificial situation of deciding who, the 
organization's many contributors, is a member. The dismay of some participants shows that formal membership fails to account for actual contribution.

1 Melany: but we're laughing, but uh but I think that it can be a big problem because euh it's

2 like... If we talk about Bernard, but if if if he's member... office of the MP is a member

$3 \mathbf{X}$ : we remove member, so it becomes partner

4 Diane: solidary or partner organizations

5 X: this way, there, we don't have to put 'member'

Melany expresses the tension between the regular participation of the local Member of Parliament's aide - Bernard - to the meetings, and that it would be strange to imply that the MP's office is a member of the Council. The solution that an unidentified participant (X) and Diane suggest consists in removing the word "member" from the label of one of the categories, so that it becomes "partner organization."

This solution, however, is not satisfactory. Another participant points out that those names would still be in the membership list, which would be sent, for example, along with grant applications.

$8 \mathbf{X}$ : yes, but doesn't it raise a problem, a bit, when you apply for a grant and that they ask you for

9 your member list, or I don't know what

10 Melany: well you send your bylaws and those members can't vote, it's clear

11 Diane: yes, but you'll agree that elected officials don't have their place

Melany suggests that sending the bylaws explaining the membership categories would account for the presence those "odd" people on the membership list. To Diane, though, the presence of elected officials on the membership list is not acceptable. Her response reveals that tweaking the name of formal categories is not enough and that more drastic decisions need to be made. 
It is again Melany who expresses the tension between the desire to work with various people and the perceived need for formal categories. She seems to understand Diane's comment regarding elected officials as implying that denying them membership would preclude their participation. Her admission - "I don’t know" - illustrates that participants are still, at this stage, caught in the blinders of formal membership.

12 Melany: yes, but there, there, there is a situation, and when the MP sends someone (ok) they're

13 observers, I don't have any problem with that

14 Diane and X: hum hum

Melany: but when they're members, I am willing to admit they can't vote, but... so, I don't

15 know

16

Further in the conversation, a form of compromise is reached. Elected officials would be explicitly excluded (because the CDC's membership may only consist of organizations) but they would be welcome as observers or guests. This consists in a first successful distinction between formal membership and presence around the table (i.e., contributorship, in this paper's jargon).

19 Diane: we can specify "excluding elected officials"

$20 \quad \mathbf{X}$ : well and uh

$21 \quad \mathbf{Z}:$ it's better to specify, yes

22 Melany: but now if elected officials want to come, what's their status

23 Several: observers

$24 \mathbf{X}$ : or guests

25 Daniel: yeah, but now, it's still an interesting question, we can exclude elected officials but what

26 do we do with boroughs and the cities. You know, imagine the borough being a member of the

27 community cooperation, it's a little bit (?) Indeed, partner, it would say that we cooperate with 
29 them, but to me it's weird to say "the city is like partner, it is a member of my community group"

However, Daniel expands the conversation and notes that the ad-hoc arrangement that is reached does not solve several similar cases, in particular the city authorities (which are regulars at Community Council meetings). Other participants give the example of the police. The suggestion is then to create an "observers" category to account for those people. However, once again, it is Melany who formulates the tension at play:

37 Melany: it's a big change, we've got to admit (xxx) with the member appellation, whether they

38 vote or even if they're not voting, it's a big change

39 Diane: hum, hum

40 Melany: of the vision of the council ((inaudible)) but if we get back to the mission there

41 X: hum hum

42 Melany: “is a multisectoral group of community organizations" the police is::: isn't a

43 community organization as far as I know. So, we must create a different category

44 X: that's it

45 Melany: observers or it's to define what are (1) partners and then after that we add observers.

46 That's it? Who are our partners?

To Melany, the changes in the labels of membership categories is important. It is unclear if her opinion is based on the fact that some people would be formally recognized as members while they were not or, on the contrary, because some people would be unable to attend Community Council meetings. Her intervention on lines 45-46, in any case, shows that she understands the "observers" category as being a formal category, on the same footing as the "partners" category. It is made necessary because of the organization's mission, which limits formal membership to community organizations. Her question, "Who are our partners?" shows 
that the distribution of the various people who attend meetings between the categories is far from being clear. Again, the boundary between formal membership and contributorship is delicate.

Following Melany's intervention, another provisional solution is reached with the proposal that membership status should depend on the candidate organization's mission. However, the deus ex machina in this conversation is Daniel, who eventually (while debates still concern MP's status as organizations) suggests a clear distinction between the formal categories under scrutiny and individuals' ability to attend the Council's meetings, that is, to contribute to the conversations and actions. Said otherwise, Daniel's intervention makes clear that "observers" do not need to be a formal category in the organization's bylaws - they may just show up and attend meetings.

85 Daniel: there it's clear that two things, the first is that those three categories uh uh do not define 86 (?) an exhaustive list of all the people who are at the table when we talk, necessarily. We're

87 talking about the members of the council.

88 Diane: that's it

89 Daniel: in addition to the members of the council there can be:

90 Diane: there are observers

91 Daniel: all the partners that need to be there for us, for themselves, for cooperation, and so on. $92[\ldots]$

Following Daniel's intervention, Diane offers a wrap-up where she stresses that the debate is sterile because few of the contributors will actually seek formal membership just because of the change in legal status. That Diane now offers such a conclusion is telling because it contrasts with her previous turns of talk in the conversation; earlier, she had a more exclusionary attitude. Daniel's solution, by distinguishing formal membership from actual participation to discussions, has allowed Diane and possibly other participants to make a similar 
distinction. Said otherwise, from that moment on, membership does not overlap with contributorship, and people are not viewed as individuals who fully belong to an organization, but rather as dividuals who may bring a contribution to multiple organizations at once. For instance, the presence of Bernard around the table does not necessarily imply that his employer, the MP's office, is welcome.

The analysis of this excerpt, while only illustrative, allows spelling out two key ideas. The first is that participants are bound - until Daniel's ultimate intervention - by a formal understanding of membership, which they view as determining people's actual behavior (e.g., whether they will or not be able to attend meetings). By thinking of organizations and people as individuals who fit into each other like Russian dolls, we limit our ability to observe how contributions are actually made. This is, according to Schoeneborn and Scherer (2012), what we as organizational communication scholars tend to think: we like to believe that formal rules of membership are sure guides of what takes place within the organizations we study. However, the above illustration shows that participants are distressed as they believe membership rules may exclude partners from attending meetings. They would not want their local MP's office, the police, or the borough to be members of the Council, but some members of those organizations have been valued contributors to their conversations. All of a sudden, they fear, those contributions would be excluded because of the membership rules they have to lay out.

Daniel finally raises the point this paper is making: there is no necessary equivalence between formal membership and actual contribution to the organization. Daniel's statement provides a breakthrough in participants' ways of thinking about membership. Indeed, Diane changes her stance following his intervention, and the group quickly reaches consensus 
afterwards (although we admit the topic of membership did arise a few times in following meetings).

\section{Discussion}

The notion of membership is closely tied to two ideas. The first is that complete and coherent individuals are the obvious origin of action, which then somehow "scales up" to the organizational "level." The second is that formal membership would, provided careful definition, unproblematically reflect actual organizational behavior. McPhee's suggestion that one of the constitutive communication flows of organizations is membership negotiation (McPhee \& Zaug, 2000), as well as Schoeneborn and Scherer's (2012) call for a focus on communicative events, allow taking a step back from such conceptions.

Yet, literature has yet to provide an interactional lens to the study the concrete performance of membership. Frank's and Jerome's trips to Paris were not “organizational” just because both men were formal members of the housing federation: it is following a series of concrete communicational practices - including the accounts made at the general meeting and the subsequent applause - that they were, retrospectively, acknowledged as having acted as contributors to the organization. In the case of the Community Council, we saw that people's hesitations over membership categories reflected their reluctance to exclude people from their discussions, and that they recognized that those people's contributions were important to the Council, irrespective of formal membership. The workaround they eventually agreed on could be understood as downplaying the importance of the categories they were defining.

Our proposal is doubly pragmatic. It calls for a focus on communicative actions - speech acts and accounts in a sense close (but not equal) to that of ethnomethodology. In turn, those 
communicative actions are performed to contribute further actions to the organization. This is what Cooren (2010), following French linguist Lucien Tesnière, calls ditransitive action: it is an action that is performed on an object, but also for someone or something else (Taylor \& Van Every, 2000). The object are those actions that become organizational in being accomplished for the organization. This, in turn, grants people the informal status of contributors, inasmuch as they are recognized or authorized to act by the organization. Recognizing contributorship as independent of membership also allows accounting for cases of usurpation of contributions, i.e., where organizations may appropriate contributions without recognizing contributorship. This draws attention to the importance of the sanction, which highlights the communicative and transactional character of membership constitution.

Our discussion of both cases solves a contradiction that has rarely been noted: organization studies literature ceaselessly discuss the action of organizations, while theoretical attempts at clarifying organizational action insist on human beings' exclusive agency (King, Felin, \& Whetten, 2010). Following Actor-Network Theory’s invitation to recognize nonhumans' contribution to collectives (Callon, 1986; Latour, 1993), a sizeable portion of organizational communication scholarship had acknowledged, for example, the contribution of texts and objects to organizational action (Brummans, 2007; Cooren, 2004a). However, conventional understandings of (formal) membership still imply that we can decide in advance a) whether humans, texts or objects belong to the organization and, more importantly, b) the nature of members and the kind of contribution they can make.

In the case of the housing federation, Frank and Jerome both spoke in the name of the federation, directly. In the case of the Community Council, it could be argued that participants had the MP's aide, Bernard's personal contributions in mind when they hesitated to be overly 
strict in excluding any potential participation. Authorship of action, and deciding whether it originates from a person or an organization, in fact, is a matter of debate (Castor \& Cooren, 2006), which is why it is possible to share action with organizations in the first place.

Recognizing the importance of action in determining actual contributorship also allows acknowledging that people may, of course, be members of several organizations at once. This means they can be equally members of "their" organization and of the federations, partnerships, etc., in which it may be involved. The understanding that people are not in-dividuals but that "their" actions can variously contribute to different organizations and collectives could allow revisiting some of the literature on organizational identity and identification, which acknowledges multiplicity and fragmentation, but situates them at the level of understanding and does not question the presumed initial completeness of the individual, i.e., it focuses on individuals in search of their actions' coherence rather than on actions in search of individuality. The second view, though, would free discussions of organizational constitution and action from the need of a human "substrate," as humans and organization are in fact constituted through the same practices.

More prosaically, focusing on action and on its constitution of both organizations and contributors provides a method to uncover actual contributorship, without relying on formal definitions or even people's opinion, which, as we saw in the second case, may be misleading as to who actually sits around the table or who plays a part. By turning attention to the practices through which actions are attributed to organizations, analysts and practitioners alike can identify the people - or, indeed, the things - that are considered to share authorship with the organization or to be authorized by it: we will have found the organization's contributors - that is, its "actual" members, as opposed to those people whose name is inscribed on a roster. In contrast, we will 
also be able to identify those who are denied such authorization and who, while they may be formally members, see their action being discounted.

We have focused on community organizations, for which membership is a daily challenge. Alternate forms of work through partnerships and volunteering blur the lines of conventional organizational membership (e.g., employment established through contracts). Increasingly, changing work realities bring for-profit and government organizations closer to the precarious reality of community organizations (Barley \& Kunda, 2004). Given that a large proportion of CCO literature is founded on implicit understandings of membership, a better conception of this notion, including by grounding it on TMS's definition of communication as action (Schoeneborn et al., 2014), is crucial to opening of new avenues for research.

More theoretically, this proposal allows two different but equally important things. First, it shows that a CCO-inspired analysis may prevent us from taking membership for granted. Instead, organizational communication studies - whether CCO-inspired or not - should attempt to show how participants themselves acknowledge some contributions to be relevant or not to the organization. Contributorship to any particular (broadly defined) organization should be a conclusion, rather than a starting point, of empirical investigation. Secondly, our paper illustrates how $\mathrm{CCO}$ precepts are now mature enough to account for the communicative constitution not only of organizations as such, but also of a variety of phenomena within and around organizations, including membership. CCO allows looking at how people constitute a variety of "things" that may or not be organizations in the conventional sense of the word, but also contributorship or, as in the case of Koschmann (2013), identities, or others. 


\section{References}

Ahrne, G., \& Brunsson, N. (2005). Organizations and meta-organizations. Scandinavian Journal of Management, 21(4), 429-449.

Ainsworth, S., \& Hardy, C. (2008). The Enterprising Self: An Unsuitable Job for an Older Worker. Organization, 15(2), 389-405. http://doi.org/10.1177/1350508408088536

Amsterdamska, O. (1990). Review: Surely You Are Joking, Monsieur Latour! Science, Technology, \& Human Values, 15(4), 495-504.

Ashcraft, K. L., Kuhn, T. R., \& Cooren, F. (2009). Constitutional Amendments: "Materializing" Organizational Communication. The Academy of Management Annals, 3(1), 1-64. http://doi.org/10.1080/19416520903047186

Ashforth, B. E., \& Mael, F. (1989). Social Identity Theory and the Organization. The Academy of Management Review, 14(1), 20-39.

Austin, J. L. (1962). How to Do Things with Words. Cambridge, MA: Harvard Univ. Press.

Barley, S. R., \& Kunda, G. (2004). Gurus, hired guns, and warm bodies : itinerant experts in a knowledge economy. Princeton, NJ: Princeton University Press.

Bencherki, N., \& Cooren, F. (2011). To have or not to be: the possessive constitution of organization. Human Relations, 64(12), 1579-1607.

http://doi.org/10.1177/0018726711424227

Benoit-Barné, C., \& Cooren, F. (2009). The Accomplishment of Authority Through Presentification: How Authority Is Distributed Among and Negotiated by Organizational Members. Management Communication Quarterly, 23(1), 5-31. http://doi.org/10.1177/0893318909335414

Boltanski, L., \& Thévenot, L. (2006). On Justification: Economies of Worth. Princeton, NJ: Princeton University Press. 
Brannick, T., \& Coghlan, D. (2007). In Defense of Being "Native": The Case for Insider Academic Research. Organizational Research Methods, 10(1), 59-74.

Brummans, B. H. J. M. (2006). The Montréal School and the question of agency. In F. Cooren, J. R. Taylor, \& E. J. Van Every (Eds.), Communication as organizing: Empirical and theoretical explorations in the dynamic of text and conversation (pp. 197-211). Mahwah, NJ: Lawrence-Erlbaum.

Brummans, B. H. J. M. (2007). Death by document: Tracing the agency of a text. Qualitative Inquiry, 13(5), 711-727.

Burke, K. (1950). A rhetoric of motives. N.Y.,: Braziller.

Butler, C. W., \& Fitzgerald, R. (2010). Membership-in-action: Operative identities in a family meal. Journal of Pragmatics, 42(9), 2462-2474. http://doi.org/10.1016/j.pragma.2010.03.006

Callon, M. (1986). Some elements of a sociology of translation: domestication of the scallops and the fishermen of St Brieuc Bay. In J. Law (Ed.), Power, action and belief: a new sociology of knowledge? (pp. 196-223). London: Routledge.

Castor, T., \& Cooren, F. (2006). Organizations as Hybrid forms of Life: The Implications of the Selection of Agency in Problem Formulation. Management Communication Quarterly, 19(4), 570-600. http://doi.org/10.1177/0893318905284764

Chaput, M., Brummans, B. H. J. M., \& Cooren, F. (2011). The Role of Organizational Identification in the Communicative Constitution of an Organization: A Study of Consubstantialization in a Young Political Party. Management Communication Quarterly, 25(2), 252-282. http://doi.org/10.1177/0893318910386719 
Cheney, G. (1983). On the various and changing meanings of organizational membership: A field study of organizational identification. Communication Monographs, 50(4), 342362. http://doi.org/10.1080/03637758309390174

Cooren, F. (2004a). Textual agency: How texts do things in organizational settings. Organization, 11(373-393).

Cooren, F. (2004b). The Communicative Achievement of Collective Minding: Analysis of Board Meeting Excerpts. Management Communication Quarterly, 17(4), 517-551. http://doi.org/10.1177/0893318903262242

Cooren, F. (2006). The organizational world as a plenum of agencies. In F. Cooren, J. R. Taylor, \& E. J. Van Every (Eds.), Communication as organizing: Practical approaches to research into the dynamic of text and conversation (pp. 81-100). Mahwah, NJ: Lawrence Erlbaum.

Cooren, F. (2007). Interacting and organizing : analyses of a management meeting.

Cooren, F. (2010). Action and Agency in Dialogue: Passion, Ventriloquism and Incarnation. Amsterdam/Philadelphia: John Benjamins.

Cooren, F., \& Fairhurst, G. T. (2008). Dislocation and Stabilization: How to Scale Up from Interactions to Organization. In L. L. Putnam \& A. M. Nicotera (Eds.), The Communicative Constitution of Organization: Centering Organizational Communication (pp. 117-152). Mahwah, NJ: Lawrence Erlbaum Associates.

Cooren, F., Fox, S., Robichaud, D., \& Talih, N. (2005). Arguments for a plurified view of the social world: Spacing and timing as hybrid achievements. Time \& Society, 14(2-3), 265282. 
Davis, F. (1973). The Martian and the Convert: Ontological Polarities in Social Research. Journal of Contemporary Ethnography, 2(3), 333-343. http://doi.org/10.1177/089124167300200305

Deleuze, G. (1992). Postscript on the Societies of Control. October, 59, 3-7.

Derrida, J. (1991). L'autre cap ; suivi de La démocratie ajournée. Paris: Editions de Minuit.

Ganesh, S., \& McAllum, K. (2012). Volunteering and Professionalization: Trends in Tension? Management Communication Quarterly, 26(1), 152-158. http://doi.org/10.1177/0893318911423762

Garfinkel, H. (1967). Studies in ethnomethodology. Englewood Cliffs, N.J.,: Prentice-Hall.

Giddens, A. (1984). The constitution of society : outline of the theory of structuration. Cambridge: Polity Press.

Goodall, H. L. (2000). Writing the New Ethnography. Walnut Creek: Alta Mira Press.

Gossett, L. M. (2006). Falling between the Cracks: Control and Communication Challenges of a Temporary Workforce. Management Communication Quarterly, 19(3), 376-415. http://doi.org/10.1177/0893318905280327

Have, P. T. (2002). The Notion of Member is the Heart of the Matter: On the Role of Membership Knowledge in Ethnomethodological Inquiry. Forum Qualitative Sozialforschung / Forum: Qualitative Social Research, 3(3). Retrieved from http://www.qualitative-research.net/index.php/fqs/article/view/834

Heaphy, E. D. (2013). Repairing Breaches with Rules: Maintaining Institutions in the Face of Everyday Disruptions. Organization Science, 24(5), 1291-1315. http://doi.org/10.1287/orsc.1120.0798 
Henderson, A., Cheney, G., \& Weaver, C. K. (2015). The Role of Employee Identification and Organizational Identity in Strategic Communication and Organizational Issues Management about Genetic Modification. International Journal of Business Communication, 52(1), 12-41. http://doi.org/10.1177/2329488414560278

Hogg, M. A., \& Reid, S. A. (2006). Social Identity, Self-Categorization, and the Communication of Group Norms. Communication Theory, 16(1), 7-30. http://doi.org/10.1111/j.14682885.2006.00003.x

Huxham, C., \& Vangen, S. (2000). Ambiguity, Complexity and Dynamics in the Membership of Collaboration. Human Relations, 53(6), 771-806.

http://doi.org/10.1177/0018726700536002

Hylmö, A. (2006). Telecommuting and the Contestability of Choice: Employee Strategies to Legitimize Personal Decisions to Work in a Preferred Location. Management Communication Quarterly, 19(4), 541-569. http://doi.org/10.1177/0893318905284762

James, W. (1977). What Pragmatism Means. In J. J. McDermott (Ed.), The Writings of William James. A Comprehensive Edition (pp. 376-390). Chicago: Chicago University Press.

Jefferson, G. (2004). Glossary of transcript symbols with an introduction. In G. H. Lerner (Ed.), Conversation Analysis: Studies from the first generation (pp. 13-31). Amsterdam/Philadelphia: John Benjamins.

King, B. G., Felin, T., \& Whetten, D. A. (2010). Perspective-Finding the Organization in Organizational Theory: A Meta-Theory of the Organization as a Social Actor. Organization Science, 21(1), 290-305. http://doi.org/10.1287/orsc.1090.0443 
Koschmann, M. A. (2013). The Communicative Constitution of Collective Identity in Interorganizational Collaboration. Management Communication Quarterly, 27(1), 61-89. http://doi.org/10.1177/0893318912449314

Kuhn, T., \& Nelson, N. (2002). Reengineering Identity: A Case Study of Multiplicity and Duality in Organizational Identification. Management Communication Quarterly, 16(1), 5-38. http://doi.org/10.1177/0893318902161001

Latour, B. (1993). We have never been modern. Cambridge, MA: Harvard University Press.

Latour, B. (2008). What is the Style of Matters of Concern? Assen, The Netherlands: Royal Van Gorcum.

Lawrence, T. B. (2004). Rituals and Resistance: Membership Dynamics in Professional Fields. Human Relations, 57(2), 115-143. http://doi.org/10.1177/0018726704042924

Lee Ashcraft, K., \& Allen, B. J. (2003). The Racial Foundation of Organizational Communication. Communication Theory, 13(1), 5-38. http://doi.org/10.1111/j.14682885.2003.tb00280.x

Lenoir, T. (1994). Was the Last Turn The Right Turn? The Semiotic Turn and A. J. Greimas. Configurations, 2(1), 119-136.

McAllum, K. (2014). Meanings of Organizational Volunteering Diverse Volunteer Pathways. Management Communication Quarterly, 28(1), 84-110. http://doi.org/10.1177/0893318913517237

McNamee, L. G., \& Peterson, B. L. (2014). Reconciling “Third Space/Place” Toward a Complementary Dialectical Understanding of Volunteer Management. Management Communication Quarterly, 28(2), 214-243. http://doi.org/10.1177/0893318914525472 
McPhee, R. D., \& Iverson, J. (2009). Agents of constitution in Communidad: Constitutive processes of communication in organization. In L. L. Putnam \& A. M. Nicotera (Eds.), Building theories of organization: The constitutive role of communication (pp. 49-87). New York, NY: Routledge.

McPhee, R. D., \& Zaug, P. (2000). The communicative constitution of organizations: A framework for explanation. Electronic Journal of Communication, 10(1-2). Retrieved from http://www.cios.org/EJCPUBLIC/010/1/01017.html

Meisenbach, R. J., \& Kramer, M. W. (2014). Exploring Nested Identities Voluntary Membership, Social Category Identity, and Identification in a Community Choir. Management Communication Quarterly, 28(2), 187-213. http://doi.org/10.1177/0893318914524059

Munro, R. (1999). Power and Discretion: Membership Work in the Time of Technology. Organization, 6(3), 429-450. http://doi.org/10.1177/135050849963004

Osborne, S. P., \& Flynn, N. (1997). Strategic Alliances Managing the Innovative Capacity of Voluntary and Non-Profit Organizations in the Provision of Public Services. Public Money \& Management, 17(4), 31-39. http://doi.org/10.1111/1467-9302.00089

Pratt, M. G. (2000). The Good, the Bad, and the Ambivalent: Managing Identification among Amway Distributors. Administrative Science Quarterly, 45(3), 456-493.

Putnam, L. L., \& Nicotera, A. M. (2009). Building Theories of Organization: The Constitutive Role of Communication. Mahwah, NJ: Lawrence Erlbaum.

Raman, S. (2001). Offshored Workers or New Intellectuals? Emerging from the Great Labour Divide in University Research. Organization, 8(2), 441-447. http://doi.org/10.1177/1350508401082029 
Richardson, L. (2000). Writing: A method of inquiry. In Y. S. Lincoln \& N. K. Denzin (Eds.), Handbook of qualitative research (pp. 923-948). Thousand Oaks, CA: Sage.

Schoeneborn, D., Blaschke, S., Cooren, F., McPhee, R. D., Seidl, D., \& Taylor, J. R. (2014). The Three Schools of CCO Thinking: Interactive Dialogue and Systematic Comparison. Management Communication Quarterly, 28(2), 285-316.

http://doi.org/10.1177/0893318914527000

Schoeneborn, D., \& Scherer, A. G. (2012). Clandestine Organizations, al Qaeda, and the Paradox of (In)Visibility: A Response to Stohl and Stohl. Organization Studies, 33(7), 963-971. http://doi.org/10.1177/0170840612448031

Scott, C. R., Corman, S. R., \& Cheney, G. (1998). Development of a structurational model of identification in the organization. Communication Theory, 8(3), 298-336. http://doi.org/10.1111/j.1468-2885.1998.tb00223.x

Searle, J. R. (1969). Speech acts: an essay in the philosophy of language. London: Cambridge U.P. Retrieved from http://www.loc.gov/catdir/description/cam041/68024484.html Simondon, G. (2005). L'individuation à la lumière des notions de forme et d'information. Grenoble: Jérôme Millon.

Stohl, C., \& Stohl, M. (2011). Secret Agencies: The Communicative Constitution of a Clandestine Organization. Organization Studies, 32(9), 1197-1215. http://doi.org/10.1177/0170840611410839

Tarde, G. (1893). Monadologie et sociologie. (J.-M. Tremblay, Ed.). Chicoutimi, QC: J.-M. Tremblay. 
Taylor, J. R., Flanagin, A. J., Cheney, G., \& Seibold, D. R. (2001). Organizational communication research: Key moments, central concerns, and future challenges. Communication Yearbook, 24, 99-138.

Taylor, J. R., \& Van Every, E. J. (2000). The emergent organization : communication as its site and surface. Mahwah, N.J.: Lawrence Erlbaum Associates.

Taylor, J. R., \& Van Every, E. J. (2011). The situated organization: Studies in the pragmatics of communication research. New York, NY: Routledge.

Taylor, J. R., \& Van Every, E. J. (2014). When Organization Fails: Why Authority Matters. New York, NY: Routledge.

Tsoukas, H., \& Chia, R. (2002). On Organizational Becoming: Rethinking Organizational Change. Organization Science, 13(5), 567-582.

Van Maanen, J. (1979). The Fact of Fiction in Organizational Ethnography. Administrative Science Quarterly, 24(4), 539-550.

van Vuuren, M., \& Cooren, F. (2010). "My Attitude Made Me Do It": Considering the Agency of Attitudes. Human Studies, 33(1), 85-101. http://doi.org/10.1007/s10746-010-9137-x

Vásquez, C. (2013). Spacing Organization: Or How to be Here and There at the Same Time. In D. Robichaud \& F. Cooren (Eds.), Organization and Organizing: Materiality, Agency and Discourse (pp. 127-149). New York, NY: Routledge.

Weick, K. E. (1979). The social psychology of organizing (2d ed.). Reading, MA: AddisonWesley.

Weick, K. E. (1995). Sensemaking in organizations. Thousand Oaks: Sage Publications. Retrieved from http://www.loc.gov/catdir/enhancements/fy0655/95008203-d.html 
Wright, C. (2009). Inside Out? Organizational Membership, Ambiguity and the Ambivalent Identity of the Internal Consultant. British Journal of Management, 20(3), 309-322. http://doi.org/10.1111/j.1467-8551.2008.00585.x

${ }^{\text {i }}$ All names have been changed to preserve anonymity.

ii We only loosely follow the transcription convention suggested by Jefferson (2004) to ensure readability and given that our argument does not require us to consider, for example, overlaps in talk or the exact timing of pauses. " $\mathrm{X}$ " and " $Z$ " indicates that we were unable to identify the speaker. 